UDC 621.316.11

\title{
RESEARCH INFLUENCE OF ANALYTICALLY CALCULATED AND REAL ELECTRICAL LOAD OF MULTFLAT HOUSING IN CHOICE OF POWER OF INTER-QUARTERLY SUBSTATIONS
}

\author{
A. S. Bondarchuk, E. P. Nechiporuk \\ Odessa National Polytechnic University
}

\begin{abstract}
The studies were conducted on four 216-apartment buildings, which account for a $10 / 0.4 \mathrm{kV}$ substations. Built by spline interpolation in the MathCAD environment, the charts of the electrical load of homes by standard indicators and based on information measurement. Turning the obtained graphs into two stages, the parameters of the rated capacities of the oil transformers 400 and $250 \mathrm{kVA}$ were chosen by their parameters, since the rated power by the standards turned out to be much higher than the actual one. The variant with the TM-250/10 transformer, will save (energy efficiency) by reducing electricity losses during operation about 492,2 tons conditional fuel, in case of electricity loss (economic efficiency), the option is cheaper by UAH 268,2 thousands, which will result in emission reductions (environmental efficiency) of about 163,6 tons.
\end{abstract}

Keywords: electrical load, apartment building, spline interpolation, efficiency, quarterly substation.

\section{The urgency of the problem.}

The schedule of daily electric load of apartment buildings, as an accidental realization of some random process, is formed from a considerable number of electrical loads of individual electric receivers (ER) of dwellings, common buildings. Precise determination of load is an urgent problem because it plays a decisive role in the choice of economic power supply system (PSS), its elements (lowering substations, sections of current-carrying parts of overhead, cable lines, etc.), protection and automation systems, etc.

The problem of accurately calculating the electrical load of civilian objects requires an up-todate approach to calculating it, since the use of existing regulations of the State Building Codes (SBC) leads to a significant excess of the actual load, as evidenced by the results of the studies. This has a significant impact on the capital costs of selecting, constructing and operating the PSS, so the relevance of the topic chosen is obvious.

\section{Analysis of recent research and publica-} tions.

Analytical review of scientific publications indicates that the first publications on the study and justification of electrical loads appeared in the early twentieth century. A significant number of leading scientists have made a significant contribution to the development of theory and practice regarding modern standards, design and operation of power systems, PSS of industrial enterprises [8-11]. However, for the practical design of PSS civilian objects, they

(C) Bondarchuk A. S., Nechiporuk E. P., 2020 generally use current regulations that require the use of demand coefficient, specific load per unit area, $\mathrm{kW} / \mathrm{m}^{2}$, or the number of dwellings (cottages), or per unit, $\mathrm{kW} /$ site.

They are given to pre-determine the load on the inputs to the objects with the subsequent use of coefficients, the differences of these loads to the maximum to select the elements of the electrical networks from the consumer to the power sources. Such standards define such parameters as average maximum, standard deviations, mean errors, which greatly exceed the final result of the calculated load calculation $[1-4,6]$. The electrical loads of dwellings, dwellings and houses are random and differ from each other, since they depend on the power, quantity, mode of operation of ER and change substantially during the day, day of the week, season of the year and are calculated analytically by power supply system as follows [4-6]:

$$
P_{c . f}=p_{\text {s.c.f }} N,
$$

where $p_{\text {s.c.f }}$ - specific estimated active electrical load of the dwelling, which is selected depending on the accepted level of electrification and the number of apartments connected to the given link of the electric grid, kW / dwelling; $N$ - is the number of dwellings (apartments) connected to the line, input.

The estimated load of residential buildings, civilian objects, analytically determined by the SBC, requires comparison with the actual electrical load

\section{An unresolved part of the overall problem}

At the same time, in the mentioned and similar studies, special attention is paid, as a rule, to electri- 
cal loads of power systems, industrial enterprises, but the issues of precise determination of the calculated loads of civilian objects remain without sufficient attention.

\section{Purpose and formulation of the research task}

The purpose of the work is to compare the accuracy of the calculation of the calculated electrical load of four 216-flats completely occupied by residents of houses with gas stoves as determined analytically by the SBC (2003-2010) and the measured value and to evaluate the impact of the results obtained on the choice of quarterly substation power, that feeds them. To achieve this goal in the work, you must solve the following tasks:

- to determine analytically at the SBC the estimated electrical load of the buildings supplied by the substation;

- to determine modeling according to automated system of commercial accounting of the electric power (ASCAEP) real load of four 216apartment buildings;

- assess the energy, economic and environmental performance of the impact of analytically calculated and obtained in 30 minutes of discretization of information of the ASCAEP of loading of four houses on the choice of capacity of a twotransformer substation, which according to the backbone (radial) scheme feeds these houses.

\section{Outline of the main material}

The research is based on the modeling of the spline theory of information on the electrical load of residential buildings based on the SBC indicators and ASCAEP information. Splines, as a simulation tool, ensure continuity and high precision of graph approximation with the appropriate choice of partitioning. It is known that the spline is a function $\mathrm{s}_{\mathrm{m}}(\Delta \mathrm{n} ; \mathrm{x})$ defined on the segment $[\mathrm{a}, \mathrm{b}]$, which coincides on the partial segments $\left[\mathrm{x}_{\mathrm{i}}, \mathrm{x}_{\mathrm{i}}++1\right]$ formed by the corresponding grid $\Delta \mathrm{n}$ : $\mathrm{a}=\mathrm{x}_{0}<\mathrm{x}_{1}$ $<\ldots<\mathrm{x}_{\mathrm{n}}=\mathrm{b}$ with algebraic polynomials of degree not higher than $\mathrm{m}$, and which has a continuous (m-1) derivative of [a, b] [7].

Spline interpolation is a spline interpolation that takes the $\left\{\mathrm{f}\left(\mathrm{x}_{\mathrm{i}}\right)\right\}$ points $\left\{\mathrm{f}\left(\mathrm{x}_{\mathrm{i}}\right)\right\}, \mathrm{i}=0,1, \ldots, \mathrm{n}$ at points $\left\{\mathrm{x}_{\mathrm{i}}\right\}$, which we use to simulate the electrical load of hour apartment buildings in MathCAD and determine load factors of transformers before overloading, for example, from 0 to $20.41 \mathrm{~h}$, and for its duration from 20.41 to $23.11 \mathrm{~h}$ (Fig. 1).

The estimated load of the houses measured in the winter regime on 20.12.2017 is higher than in the summer, taking into account the intensive work of air-conditioners in hours.

The estimated full load of four houses is analytically is determined by the following formula $[4,5]$ :

$$
S_{c 1}=\frac{p_{\text {s.c.f }} N+0,9 P_{p o w}}{\cos \varphi},
$$

where $N$ - is the number of apartments in four houses, 864 is accepted; $P_{\text {pow }}$ estimated load of other common power ER.

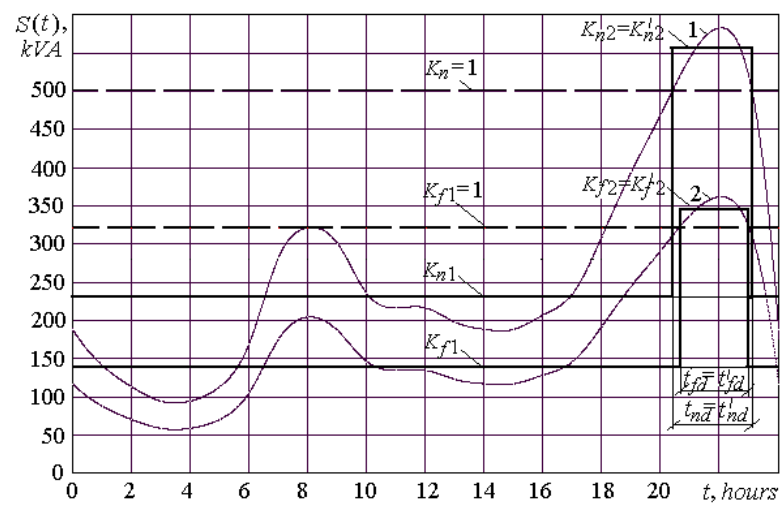

Fig. 1. Result of building schedules of load of buildings according to SBC (1) and actual (2) for

Wednesday, December 20, 2017, and their transformation into equivalent two-stage

The initial load factor calculated from the SBC power transformer is determined by the formula:

$$
K_{n 1}=\frac{1}{2 S_{n . t 1}} \sqrt{\frac{\int_{0}^{20,41} S_{c 1}^{2}(t) d t+\int_{23,11}^{24,0} S_{c 1}^{2}(t) d t}{21,3} .}
$$

When

$$
K_{n 2}^{\prime} \geq 0,9 S_{c 1} / 2 S_{n . t 1} \text {, то, } K_{n 2}=K_{n 2}^{\prime} \mathrm{i} t_{n . d}=t_{n . d}^{\prime} .
$$

If $K_{n 2}^{\prime}<0,9 S_{c 1} / 2 S_{n o m . t 1}$, then

$$
t_{n . d}=\frac{\left(K_{n 2}^{\prime}\right)^{2} t_{n . d}^{\prime}}{\left(0,9 S_{c 1} / 2 S_{n o m . t 1}\right)^{2}} .
$$

The overload, calculated by its duration $\mathrm{t}_{d 2}$, is similar to the parameters of the graph 1 .

Pre-selected for two-transformer TS-10 / 0,4 power of power oil transformers from the standard series of 160, 250 and $400 \mathrm{kVA}$ for power supply of four houses.

In terms of technical capabilities, the standard rated capacities of the $2 \times \mathrm{TM}-400 / 10$ and $2 \times \mathrm{TM}-$ 
250/10 transformers are finally selected, respectively, based on the rated output of $562.3 \mathrm{kVA}$ calculated by the SBC and the actual $361.5 \mathrm{kVA}$, as determined by the measurement. It is assumed that the fill factors (configuration) of graphs 1,2 are similar.

The annual losses of active electricity in twowinding transformers are is defined as:

$$
\Delta W_{t . \text { year }}=\Delta P_{\mathrm{c} . n o m} \beta^{2} \tau+\Delta P_{s t} T_{s} k W h,
$$

where $\Delta P_{\text {cnom }}, \Delta P_{\text {st }}-$ losses in copper and steel respectively; $\beta$-transformer load factor; $\tau-$ loss time, determined by the time of maximum power utilization and; $T_{s}$ - transformer start time during the year [4].

Using the technical data, the annual electricity losses in power transformers $2 \times \mathrm{TM}-400 / 10$ and $2 \times$ TM-250/10, respectively, are calculated. The difference in electricity losses in other elements of the PSS is not taken into account due to their insignificant value.

\section{Conclusions}

According to the results of the calculations, the variant with $2 \times \mathrm{TM}-250 / 10$ transformers will save (energy efficiency) by reducing the electricity losses during operation about 492.2 tons. According to the report, in the case of electricity loss (economic efficiency), the variant is cheaper by UAH 268.2 thousand and emission reductions (environmental efficiency) will be about 163.6 tons.

The ways of further research may be to apply the proposed comparative methodology for the electrical load of industrial enterprises and other objects of various purposes.

\section{References}

1. Bunn, D. W. (1985). Comparative models for electrical load forecasting Chichester, New York, Brisbane, Toronto: Jone \& Sons. -200 p.

2. Bondarchuk, A. S. (2017). Development of the graphoanalytic method for calculating the electrical load of civilian objects Eastern European Journal of Advanced Technologies. - Kh. - No. 4 P. 4-9.

3. Bondarchuk, A. S., Lezhniuk, P. D. (2017). A graphic method for the research into electrical load dynamics in residential apartments Compytational Problems of Electrical Engineering. - Lviv: Lviv Polytechnic National University, volume 7, number 2, pp. 73-77.

4. Bondarchuk, A. S. (2015). Indoor power supply [Vnutrishnobudynkove elektropostachannya] - K.: Osvita Ukrayiny, $-480 \mathrm{p}$.

5. Burbelo, M. J. Biryukov, O. O., Melnychuk, L. M. (2011). Power supply systems. Elements of theory and examples of calculations [Systemy elektro-postachannya. Elementy teoriyi ta pryklady rozraxunkiv] - Vinnycya: VNTU. - 204 p.

6. DBN V. 23-23-2010. Design of electrical equipment for civil purposes [Proektuvannya elektroobladnannya ob'yektiv tsyvilnoho pryznachennya]. - K: Minrehionbud. - 164 s.

7. Lezhniuk, P., Vishnevsky, S., Semeniuk, N. (2001). Simulation of the loading of electric networks by cubic splines in adaptive SAC with advance - Lviv: Lviv Polytechnic. - P. 85-87.

8. Chernenko, P. O., Martynyuk, O. V. (2012). Enhancing the Effectivencess of Short-Term Forecasting of Electric Load of United Power System Tekhnichna electrodinamika,1, P. 63-70.

9. Razumnyy, YU. T., Rukhlov, A. V., Rukhlova, N. YU. (2014) Efficient use of electricity and fuel [Efektyvne vykorystannya elektroenerhiyi ta palyva] - Dnipropetrovsk: NHU, - $223 \mathrm{~s}$.

10. Sokolova, N. P. (2014). Modeling and software for forecasting electricity consumption by airport facilities [Modelyuvannya ta programne zabezpechennya prognozuvannya spozhy`vannya elektry`chnoyi energiyi ob'yektamy` aeroportu] Vostochno-Evropejsky $\mathrm{j}$ zhurnal peredovykh texnology`j, 2, 8 (68), P. 8-12.

11. Alfares, H. K. (2002) Electric load forecasting: literature survey and classification of methods International Journal of Systems Science.. - № 33. - P. 23-34.

\title{
ДОСЛІДЖЕННЯ ВПЛИВУ АНАЛІТИЧНО ОБЧИСЛЕНОГО І РЕАЛЬНОГО ЕЛЕКТРИЧНОГО НАВАНТАЖЕННЯ БАГАТОКВАРТИРНИХ БУДИНКІВ НА ВИБІР ПОТУЖНОСТІ МІЖКВАРТАЛЬНИХ ПІДСТАНЦІЙ
}

Бондарчук А. С., Нечипорук Є. П.

Одеський національний політехнічний університет

\begin{abstract}
Анотація. Надана оцінка впливу обчислених різними методами розрахункового навантаження багатоквартирних будинків на вибір потужності міжквартальних підстанцій. Проблема точного обчислення електричного навантаження об 'єктів ичиільного призначення вимагає новітнього підхо-
\end{abstract}


ду до його розрахунку, оскільки використання чинних нормативних документів призводить до значного перевищення фактичного навантаження. Це значною мірою впливає на капітальні витрати при виборі електричного устаткування, перерізу живильних ліній, спорудженні та експлуатації систем електропостачання таких об'єктів. Дослідження проводилося на прикладі електропостачання 4-х 216-квартирних будинках, які живляться від понижувальної підстанцї напругою 10/0,4 кВ. Побудовано за допомогою сплайнової інтерполячії в середовищі МаthCAD графіки електричного навантаження будинків за нормативними показниками і на базі інформації АСКОЕ. Перетворивии отримані графіки електричного навантаження 4-х 216-квартирних будинків в еквівалентні двоступеневі, за параметрами яких обрані оливні трансформатори $2 \times 400$ mа $2 \times 250 \kappa B A$, оскільки розрахункова потужність за нормативними показниками виявилася значно вище фактичної. За технічними параметрами і економічними показниками варіант з трансформаторами $2 \times T M-250 / 10$, щуо визначені за реальним навантаженням, заощадить (енергетична ефективність) за рахунок зменшення втрат електроенергії, за час експлуатації близько 492,2 m умовного палива. Через зменшення втрат електроенергії та вартості трансформаторів (економічна ефективність) виявилось, щзо такий варіант на 268,2 тис. грн дешевший, при цььому зменшуватимуться викиди (екологічна ефективність) у довкілля близько 163,6

Ключові слова: електричне навантаження, багатоквартирний будинок, сплайнова інтерполяція, ефективність, міжквартальна підстанція.

\title{
ИССЛЕДОВАНИЕ ВЛИЯНИЯ АНАЛИТИЧЕСКИ ВЫЧИСЛЕННОЙ И РЕАЛЬНОЙ ЭЛЕКТРИЧЕСКОЙ НАГРУЗКИ МНОГОКВАРТИРНИХ ДОМОВ НА ВЫБОР МОЩНОСТИ МЕЖКВАРТАЛЬНЫХ ПОДСТАНЦИЙ
}

\author{
Бондарчук А. С., Нечипорук Е. П. \\ Одесский наџиональный политехнический университет
}

\begin{abstract}
Аннотация. Дана оченка влияния полученных разными методами расчетной нагрузки многоквартирных домов на выбор мощиности межквартальных подстанций. Исследование проводилось на примере 4-х 216-квартирных домах, которые питаются от подстанции напряжением 10/0,4 кB. Построены с помощьюю сплайновой интерполящии в среде МаthСАD графики электрической нагрузки домов по нормативным показателям и на базе информации АСКУЭ, и по их параметрам выбраны мощности масляных трансформаторов $2 \times 400$ и $2 \times 250 \kappa$ кА. По техническим параметрам и экономическим показателям вариант с трансформаторами $2 \times$ ТМ-250/10 сэкономит (энергетическая эффективность) за счет уменьшения потерь электроэнергии за время эксплуатации около 492,2 y. т. Из-за меньших потерь электроэнергии и стоимости трансформаторов (экономическая эффективность) вариант на 268,2 тыс. грн дешевле, при этом уменьшаться выбросы (экологическая эффективность) в окружаюшую среду около 163,6 m.
\end{abstract}

Ключевые слова: электрическая нагрузка, многоквартирный дом, сплайновая интерполяция, эффективность, межквартальная подстаничия

Received 06.01.2020

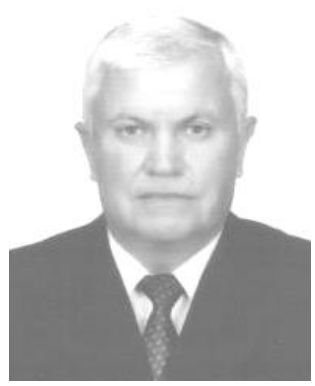

Bondarchuk Anatolii, Odessa National Polytechnic University, Candidate of Technical Sciences, Associate Professor, Associate Professor of the Department of Power Supply and Energy Management. Ave. Shevchenko, 1, Odessa, Ukraine. E-mail: asb@te.net.ua Бондарчук Анатолій Сергійович, Одеський національний політехнічний університет, кандидат технічних наук, доцент, доцент кафедри електропостачання та енергетичний менеджмент. Просп. Шевченка, 1, Одеса, Україна. E-mail: asb@te.net.ua, тел. (048)734-86-90

ORCID ID: 0000-0003-1232-5403

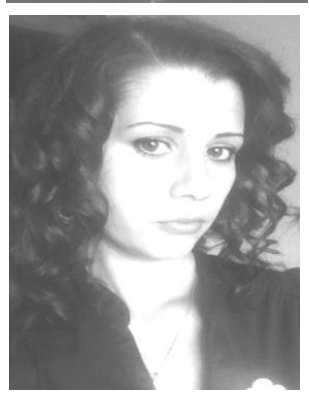

Nechiporuk Evgeniya Pavlivna, Odessa National Polytechnic University, Master, Assistant of the Department of Power Supply and Energy Management. Ave.

Shevchenko, 1, Odessa, Ukraine. Email: iriskis1988@gmail.com

Нечипорук Євгенія Павлівна, Одеський національний політехнічний університет, магістр, асистент кафедри електропостачання та енергетичний менеджмент. Просп. Шевченка, 1, Одеса, Україна. E-mail: iriskis1988@gmail.com, тел. (048)34-68-55.

ORCID ID: 0000-0002-8443-2446 